\title{
Extraction, Purification and Characterization of Peroxidase from Pseudomonas aeruginosa and Utility as Antioxidant and Anticancer
}

\author{
Entesar H. Ali \\ Karrar R. Mohammed * \\ Received 10/8/2018, Accepted 7/1/2019, Published 1/12/2019 \\ This work is licensed under a Creative Commons Attribution 4.0 International License.
}

\begin{abstract}
Peroxidase is a class of oxidation-reduction reaction enzyme that is useful for accelerating many oxidative reactions that protect cells from the harmful effects of free radicals. Peroxidase is found in many common sources like plants, animals and microbes and have extensive uses in numerous industries such as industrial, medical and food processing. In this study, $P$. aeruginosa was harvested to utilize and study its peroxidases. $P$. aeruginosa was isolated from a burn patient, and the isolate was verified as $P$. aeruginosa using staining techniques, biochemical assay, morphological, and a sensitivity test. The gram stain and biochemical test result show rod pink gram-negative bacteria, and ensure that the isolate was that of $P$. aeruginosa. Optimization for bacterial growth were done by used more than $\mathrm{pH}(5,7,9)$ and temperatures $\left(32,35,37^{\circ} \mathrm{C}\right)$, and it was found that the best growth conditions were at $\mathrm{pH} 5.5$, producing $\left(4.5 \times 10^{8}\right.$ cells), and a temperature of $37^{\circ} \mathrm{C}$, with $\left(5.25 \times 10^{8}\right.$ cells $)$ being produced. Intracellular enzymes were extracted by ultrasonication that used frequencies of ultrasound $30 \mathrm{kHz}$ for $20 \mathrm{~min}$ in $4{ }^{\circ} \mathrm{C}$, and was centrifuged at $13000 \times \mathrm{g}$ for $5 \mathrm{~min}$. The supernatant was then re-used as a crude enzymatic extract and the cell pellet was discarded. Purification of peroxidase was accomplished by using salt precipitation, dialysis, gel filtrations and ion exchange chromatographic techniques. The result shows that gel filtration has optimal specific activity and purification fold at $(61 \mathrm{U} / \mathrm{ml})$, purification fold 6 times and then the improvement enzyme was applied as $\mathrm{H}_{2} \mathrm{O}_{2}$ scavenging activity antioxidant by used three concentration of enzyme $(10,40,60 \mu \mathrm{g} / \mathrm{ml})$, and show higher scavenging activity at $60 \mu \mathrm{g} / \mathrm{ml}$, which reached to $45 \%$ scavenging activity. The enzyme was also used as anticancer agent, which was verified by using three concentration of enzyme $(10,15,20 \mu \mathrm{g} / \mathrm{ml})$ which show a significant kill for Mcf-7cells at $(15 \mu \mathrm{g} / \mathrm{ml})$, with cytotoxicity activity reaching (45\%).
\end{abstract}

Key words: Anticancer, Antioxidant, Mcf-7, Peroxidase, Pseudomonas aeruginosa.

\section{Introduction:}

Enzymes have become more important products for the food and drug industry. Peroxidase (EC.1.11.17) is characterized as an oxidationreduction enzymes, which and accelerates reaction rates among $\mathrm{H}_{2} \mathrm{O}_{2}$ as an electron acceptor and various kinds of substrates by $\mathrm{O}_{2}$ release from $\mathrm{H}_{2} \mathrm{O}_{2}$. Harmful electrons such as super oxide and hydroxide radicals, can be found in cells due to the presence of oxygen. Peroxidases use $\mathrm{H}_{2} \mathrm{O}_{2}$ as an electron acceptor which catalyzes many oxidative reactions (1). Peroxidase is an enzyme which has iron that catalyzes the transport of oxygen from hydrogen peroxide to an appropriate substrate and thus takes about oxidation of the substrate (2). There are many ways to extract enzymes depending on location.

Department of Biotechnology, College of Science, University of Technology, Baghdad, Iraq.

*Corresponding author: krarrbrca12@gmail.com
Extracellular enzymes are extracted by centrifugation and intracellular enzymes are extracted by either chemical or mechanical method such as ultra-sonication(3).

The purification of a specific enzyme involves the elimination of other substances (proteins as well as non-proteins) existing in the preparation./ Purification of the enzyme is usually more than a stepwise procedure using a range of biophysical and biochemical features, such as its relative concentration in the source, solubility, charge, size (molecular weight) and hydrophobicity/hydrophobicity of the target protein. In general, the enzyme purification is done either by (ammonium sulfate, dialysis, gel filtration or ion exchange) (4). The problem with an antioxidant drug is their interference with anticancer drugs which reduce the effect of drug, causing ulcers and nausea (5). The side-effects of cancer drugs are loss of weight, loss of hair and cost (6). The aim of this study was to improve the peroxidase yield and 
specific activity through purification, of local peroxidase enzyme that is lower cost than synthetically produced enzyme, which is used as an antioxidant and anticancer with no side effects, and to study the optimal temperature and buffer for peroxidase production from bacterial growth.

\section{Materials and Methods:}

\section{Isolation and Identification of Bacteria:}

Twenty bacterial isolate were obtained from AlYarmouk hospital from burns, UTI, and otitis media patients in 2017/11/3, and then test the best isolates for growth by spectrophotometry. It was found that the optimal isolate for enzyme production was burns isolate and identified by:

\section{Gram Stain}

A tiny bacterial smear was organized on an uncontaminated glass slide, air dehydrated and heat stabilized. The isolate was submerged with crystal violet for ( $30 \mathrm{sec}$ to $2 \mathrm{~min}$ ). The additional stain was detached by rinsing it under tap water. Later, the smear was stabilized with Gram's iodine for (1 minute) and was decolorized with alcohol, then it was washed under running tap water gently. Finally, the smear was counterstained with Safranin for (30 sec to 2 min.), with excess stain detached by washing it under tap water. The slide was spot dried with bibulous paper and experiential under 10x, 40x and 100x objective lenses (7).

\section{Biochemical Test}

Bacterial isolates were identified using (France Biomerieux API kits). First, $5 \mathrm{ml}$ of sterilized distilled water was added into the tray to offer a moist atmosphere which avoid drying of the strip and a suspension of the bacteria was used to inoculate the wells then incubate at $37^{\circ} \mathrm{C}$ overnight at (8).

\section{Morphology}

Streak plate technique was used for the isolation into pure culture of the organisms (mostly bacteria), from a mixed population. The $P$. aeruginosa was streaked over the agar surface, and some individual bacterial cells are separated and well-spaced from each other. As the original sample is diluted by streaking it over successive quadrants and then incubate at $37^{\circ} \mathrm{C}$ for $24 \mathrm{~h}$, the number of organisms' decreased and will show the bacterial morphology (9).

\section{Optimal Temperature and pH for Peroxidase Production from $P$. aeruginosa}

The bacterial suspension was cultured once at constant temperature but different $\mathrm{pH}(5.5,9$, and 7) and once at constant $\mathrm{pH}$ but different temperature $\left(32,35\right.$, and $\left.37^{\circ} \mathrm{C}\right)$, the absorbance was measured at $556 \mathrm{~nm}(10)$.

\section{Extraction of Enzyme and Proteins}

We used $60 \mathrm{ml}$ of production broth (the broth that contain the bacterial cells in which the intracellular peroxidase was found) and transported it into centrifuge tubes at $4000 \mathrm{rpm}$ for 10 minutes. Supernatant consuming extracellular protein was discarded and the pellet containing bacterial cells was collected. The mixture was sonicated by using frequencies of ultrasound $30 \mathrm{kHz}$ for $20 \mathrm{~min}$ at 4 ${ }^{\circ} \mathrm{C}$, then centrifuged in $4000 \mathrm{rpm}$ for $5 \mathrm{~min}$. The supernatant was used as a crude enzymatic extract (11).

\section{Measurement of Crude Enzyme Activity}

The activity was determined according to the methods in (12). The substrate solution was accomplished by put all the following volumes according to each ratio:

Guaicol: Hydrogen peroxide solution of $0.2 \mathrm{mM}$ : Sodium acetate solution 0.2mM: Distilled water 1: 1: 1:7 (v: v: v: v).

Three $\mathrm{ml}$ of substrate solution was added to the cell of spectrophotometer (cuvette) when it was considered as a blank solution. $0.1 \mathrm{ml}$ of enzyme solution was added and mixed well, and we measured the absorbance at 1 minute at $470 \mathrm{~nm}$ and drew the relationship between the absorbance and time. Peroxidase activity (unit activity) the amount of enzyme that oxidize $(1 \mu \mathrm{M})$ of guaicol in one minute under experiment condition.

\section{Ammonium Sulfate Precipitation}

The ratio of ammonium sulfate was determined by adding gradually the amount of salt to each 10 $\mathrm{ml}$ enzyme solution in ice bath and magnetic stirrer for $1 \mathrm{hr}$. The solution was centrifuged at 4000rpm/min for 10 minute, and then the precipitate was isolated and dissolved in $10 \mathrm{ml}$ sodium acetate $(0.2 \mathrm{mM}$ buffer $)$, and we calculated the activity and protein concentration (13).

\section{Dialysis Tube}

$15 \mathrm{ml}$ of isolated enzyme was put in the tube with $2.5 \mathrm{~cm}$ in diameter that allow molecules less than $12 \mathrm{KD}$ to pass in the sucrose solution, then the dialysis tube was put in the beaker contain sucrose for 3 hour to discard salt and retain the enzyme (14).

\section{Separation of Enzyme Through Ion Exchange Resin (DEAE Cellulose)}

The DEAE-Cellulose was accomplished along with the method suggested by Whitaker and Bernard (1972). Twenty grams from ion-exchange resin were put off in 1 liter distilled water, retained in the graduated cylinder to decay. Once the supernatant became pure, the ion exchange resin was washed away all contaminate manner by using Buchner's funnel under vacuum (without drying the ion exchange resin), then the resin was stimulated in $250 \mathrm{ml}$ from buffer ( $0.25 \mathrm{M}$ sodium hydroxide) for 30 minutes. The resin was re-filtered and washed under vacuum using distilled water, then the resin 
was solubilized in $250 \mathrm{ml}$ of $-0.25 \mathrm{M}$ hydrochloride acid with agitation for 30 minutes. After that, the resin was cleaned with distilled water under vacuum, and the resin was suspended in potassium phosphate buffer $(5 \mathrm{mM}, \mathrm{pH}=7)$, and the ion exchange resin was degassed using a vacuum pump. The resin was boxed softly in glass column $(2.5 \times 16 \mathrm{~cm})$, and the equilibration was achieved by the same potassium phosphate buffer (15) .

Enzyme Separation Through Sephadex G-200 column

The preparation of the gel was achieved as recommended by a supplied company. 20 gram of gel Sephadex G-200 powder was put off in $500 \mathrm{ml}$ distilled water and placed in a water bath at $90{ }^{\circ} \mathrm{C}$ for 3 hour and then washed twice with potassium phosphate buffer $(0.2 \mathrm{M}, \mathrm{pH}=7)$. After that, the gel was suspended, then placed in a vacuum pump, and the gel was boxed softly in glass column with dimensions $(1.5 \times 10) \mathrm{cm}(16)$.

Peroxidase $\mathrm{H}_{2} \mathrm{O}_{2}$ Scavenging Activity

The unbound electron scavenging activity of the extracts was determined by 1, 1-diphenyl-2-picrylhydrazyl (DPPH) as said by the earlier reported method by Shin. A $0.1 \mathrm{mM}$ solution of DPPH in methanol was accomplished and $1 \mathrm{~mL}$ of this solution was added to $3 \mathrm{ml}$ of the solution in methanol at different concentration (20,40,60, $\mu \mathrm{g} / \mathrm{mL}$ ). The mixtures were shaken and allowed to settle at room temperature for 30 minutes. The absorbance was measured at $517 \mathrm{~nm}$ using a UVVIS spectrophotometer, with ascorbic acid as the control. Lower absorbance values of the reaction mixture show higher free radical scavenging activity and the ability of scavenging of the DPPH radical was calculated by using the following formula DPPH scavenging effect $(\%$ inhibition $)=$ $\{(\mathrm{A} 0-\mathrm{A} 1) / \mathrm{A} 0) \times 100(17)$.

\section{Cytotoxicity of Peroxidase on MCF-7 Cells Using} MTT Assay

This assay was done in Al-Nahrain Biotechnology Research Center. MCF-7 cells were provided by Al-Nahrain Biotechnology Research and was incubated 24 hours for attachment. Peroxidase with concentrations $(20,10,5 \mu \mathrm{g} / \mathrm{mL})$ were added in triplicates and incubated for 48 hours at $5 \% \mathrm{CO}_{2}$ and $37^{\circ} \mathrm{C}$. Afterwards, the cells were treated with MTT and incubated for 4 hours. After incubation, all of the medium including MTT solution were aspirated from the wells. The absorbance was measured at $492 \mathrm{~nm}$ using ELISA Micro Plate Reader. The cytotoxicity catalogue was firm, using the untreated cells as negative control. The percentage of cytotoxicity was calculated using the background corrected absorbance follows: Where A is the optical density of control, B is the optical density of treated sample. Inhibition rate $\%$ $=(\mathrm{A}-\mathrm{B} / \mathrm{A}) \mathrm{X} 100$ (18).

\section{Statistical Analysis}

The obtained data were statically analyzed using unpaired t-test with Graph Pad Prism 6. The values were presented as the Mean \pm S.E of the three replicates of each experiment.

\section{Results and Discussion: \\ Identification of Bacteria}

The bacterial isolates were previously identified in Al-Yarmouk hospital and farther identification was done by using Gram staining, morphological, and biochemical tests to ensure that the isolates were pure and belonged to $P$. aeruginosa. The result agreed with previously identification of $P$. aeruginosa (19), as shown in Table 1 .

Table1. Identification of $P$. aeruginosa

\begin{tabular}{cc}
\hline Test & Test result \\
\hline Oxidase & $(+)$ \\
Catalase & $(+)$ \\
H$_{2}$ S production & $(-)$ \\
Urease & $(-)$ \\
Indole production & $(-)$ \\
lactose fermenter & $(-)$ \\
methyl-red & $(-)$ \\
Glucose & $(+)$ \\
& Forms 2-3mm round \\
Colonies(morphological) & colonies, smooth with \\
& irregular surface \\
Greenish color by \\
procaine stain and \\
Color and odder & fruity odder \\
& Pink rod gram (-ve) \\
bram stain &
\end{tabular}

\section{Optimal pH and Temperature for Peroxidase} Production from $P$. aeruginosa

The bacterial suspension was incubated once at constant temperature but different $\mathrm{pH}(5.5,9$, and 7) and once at constant $\mathrm{pH}$ but different temperature $\left(32,35,37^{\circ} \mathrm{C}\right)$, and the absorbance was measured at $556 \mathrm{~nm}$ and compared with the McFarland number. It was establish that the best conditions for the creation of bacteria at $\mathrm{pH} 5.5$ with $\left(4.5 \times 10^{8}\right.$ cells $)$ as compare with $\mathrm{pH}(9,7)$ with $\left(3 \times 10^{8}\right)\left(0.5 \times 10^{8}\right.$ cells $)$ respectively and a temperature of $37^{\circ} \mathrm{C}$ with bacterial number $\left(5.25 \times 10^{8}\right.$ cells $)$. It was less at $\left(32,35^{\circ} \mathrm{C}\right)$ with bacterial number $\left(2.25 \times 10^{8}\right.$, $3.5 \times 10^{8}$ cells) respectively, and this agreed with the result of (20), as in Fig.1 and 2. 


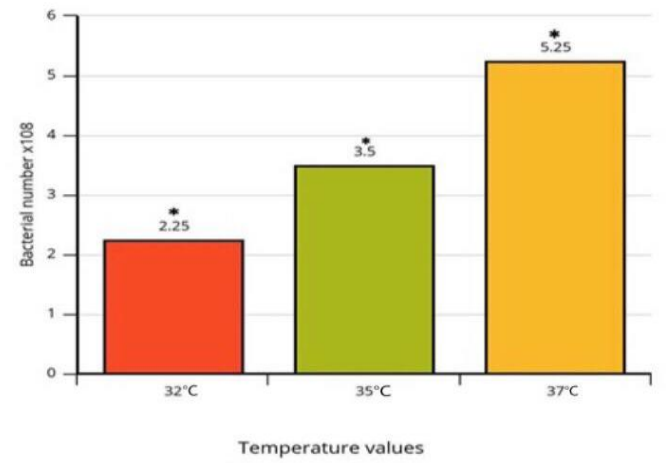

Figure 1. The optimal Temperature for Peroxidase production extracted from $P$. aeruginosa The values represents the Mean \pm S.E $* \mathbf{P}<\mathbf{0 . 0 5}$.

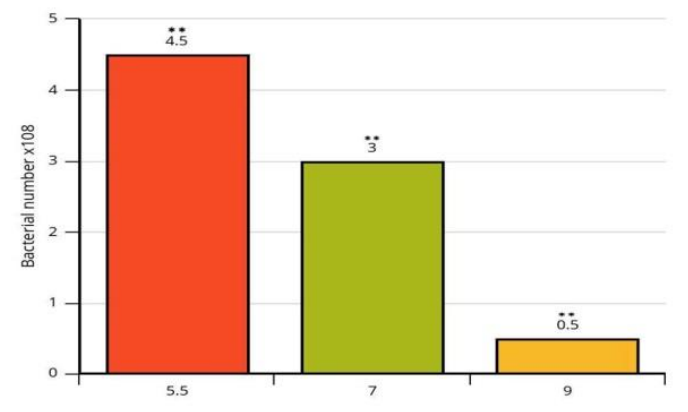

$\mathrm{pH}$ values

Figure 2. The optimal $\mathrm{pH}$ for peroxidase production extracted from P.aerugionsa The values represents the Mean \pm S.E $* * P<0.01$.

\section{Ammonium Sulfate}

The $80 \%$ ratio was chosen as the greatest ratio for precipitation of crude enzyme, in which the specific activity got to $12.64 \mathrm{U} / \mathrm{mg}$, purification 2.17 fold and yield $53 \%$, as shown in table (2). The results disagreed with (21), when they purified peroxidase from various vegetables sources, they used ammonium sulfate to precipitate peroxidase with $80 \%$ saturation ratio. The specific activity was $3.9 \mathrm{U} / \mathrm{mg}$ protein with purification 1.93 fold.

\section{Dialysis}

The results showed higher specific activity and purification than the ammonium sulfate step. The specific activity was $32.77 \mathrm{U} / \mathrm{mg}$ with purification 5.63 fold and the result was disagreed from (22), for peroxidase extract from Aspergillus niger with specific activity reached to $23 \mathrm{U} / \mathrm{mg}$.

\section{Purification Through Ion Exchange} Chromatography

As shown in the Fig.3, four protein peaks appeared in the elution and wash steps, but only one peak showed enzyme activity in the fraction number
(60-66) in the elution step. This step show increases in the specific activity and purification fold (45 $\mathrm{U} / \mathrm{mg}$ ) and (7.73 times). The result disagreed with (23), extracted peroxidase from strawberry with specific activity reached to $34 \mathrm{U} / \mathrm{mg}$ and purification was 1.17 fold.

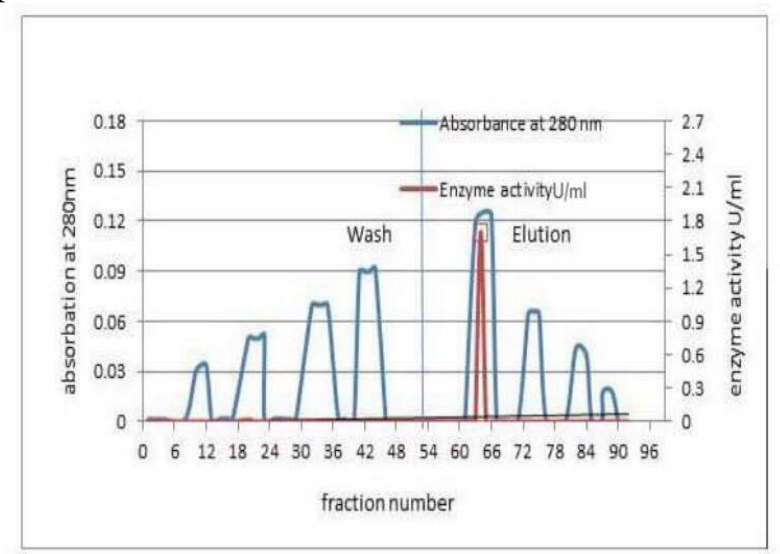

Figure 3. Ion exchange chromatography using DEAE-Cellulose column $(1.5 \times 10) \quad c m$ with

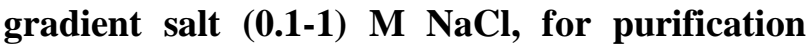
peroxidase from $P$. aeruginosa. The column was eluted with $5 \mathrm{mM}$ phosphate buffer saline with flow rate $(6 \mathrm{ml} / \mathrm{h})$ and size of fractions are $(0.1$ ml).

\section{Purification Through Gel Filtration}

As shown in Fig.4, four peaks of protein were detected, but only one peak showed activity (21$25)$. In this step, the specific activity increased to (61.36 U/mg), purification was 10.60 fold and the result was disagreed with (24), where peroxidase extracts from apple leaves was scored with specific activity at $9.2 \mathrm{U} / \mathrm{mg}$, as shown in Table 2 .

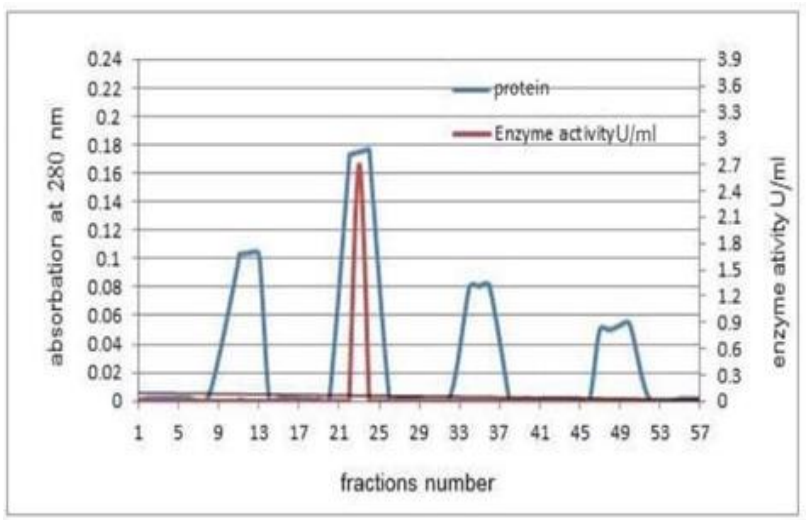

Figure 4. Gel filtration chromatography using sephadex G-200 column with dimensions $(10 \times 1.5) \mathrm{cm}$ for purification the peroxidase from $P$. aeruginosa equilibrated with phosphate buffer $0.2 \mathrm{M} \mathrm{pH}=7$, the column was washed with $5 \mathrm{mM}$ phosphate buffer saline with flow rate $(6 \mathrm{ml} / \mathrm{h})$ and fraction volume $(0.5 \mathrm{ml})$. 
Table 2. The purification steps of peroxidase enzyme

\begin{tabular}{|c|c|c|c|c|c|c|c|}
\hline Purification steps & $\begin{array}{c}\text { volume } \\
(\mathrm{ml})\end{array}$ & $\begin{array}{l}\text { Enzyme } \\
\text { activity } \\
(\mathrm{U} / \mathrm{ml})\end{array}$ & $\begin{array}{c}\text { Protein } \\
\text { concentration } \\
(\mathrm{mg} / \mathrm{ml})\end{array}$ & $\begin{array}{l}\text { Specific } \\
\text { activity } \\
\text { (U/mg) }\end{array}$ & $\begin{array}{l}\text { Total } \\
\text { activity } \\
\text { (U) }\end{array}$ & $\begin{array}{l}\text { Purification } \\
\text { fold }\end{array}$ & yield \% \\
\hline Crude enzyme & 60 & 1.34 & 0.23 & 5.82 & 80.4 & 1 & 100 \\
\hline $\begin{array}{c}\text { Ammonium sulfate } \\
\text { precipitation in } 80 \% \\
\text { ratio }\end{array}$ & 20 & 2.15 & 0.17 & 12.64 & 43 & 2.17 & 53.34 \\
\hline Dialysis tube & 10 & 2.95 & 0.09 & 32.77 & 29.5 & 5.63 & 36.70 \\
\hline $\begin{array}{l}\text { Ion exchange } \\
\text { chromatooranh }\end{array}$ & 9 & 1.8 & 0.04 & 45 & 16.2 & 7.73 & 20.14 \\
\hline $\begin{array}{c}\text { chromatograph } \\
\text { Gel filtration }\end{array}$ & 10 & 2.7 & 0.044 & 61.36 & 27 & 10.60 & 35.83 \\
\hline
\end{tabular}

Peroxidase $\mathrm{H}_{2} \mathrm{O}_{2}$ scavenging activity by DPPH:-

The peroxidase has the ability to break down $\mathrm{H}_{2} \mathrm{O}_{2}$ and other free radicals to simple compounds, so it was used as scavenging activity by used DPPH reagent, which had extra free radicals shown as red color and then converted to yellow stain by the enzyme, with the stain breaking down the free radicals and measured at $517 \mathrm{~nm}$, as shown in the Fig.5. The tube with red color is the control, while the yellow is peroxidase enzyme and the white color is ascorbic acid (control positive) against free radicals. Three enzyme concentrations were used with triplicates $(10,40,60, \mathrm{mg} / \mathrm{mL})$, The results show scavenging activity of $(20,35,43 \%)$ respectively and the result agreed with (24).

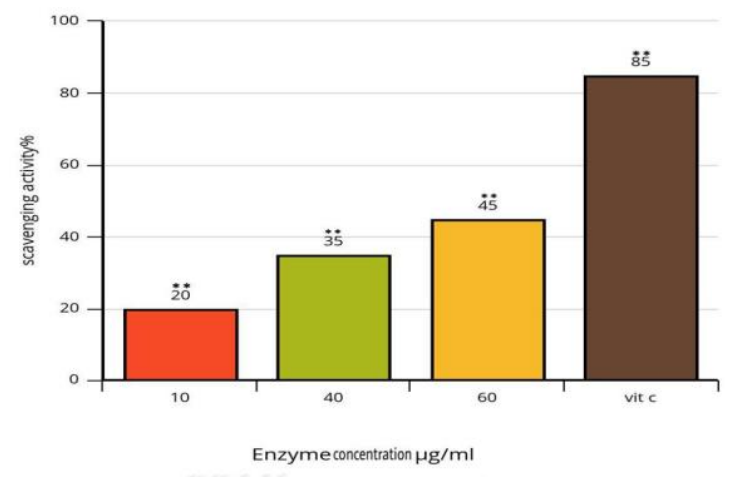

Figure 5. The relationship between enzyme concentration and scavenging activity. The values represent the Mean \pm S.E $* * \mathbf{P}<\mathbf{0 . 0 1}$.

\section{Cytotoxicity determination using MTT assay:-}

The cytotoxicity was done on MCF-7 cells by using MTT stain, which is a colorimetric method dependent on the conversion of yellow tetrazolium salt to purple formazan crystals according to cellular activity. By using three enzyme concentration with triplicate $(10,15,20, \mu \mathrm{g} / \mathrm{ml})$ and incubated for 48 hours In the $\mathrm{CO}_{2}$ incubator, the results show that the concentration of control cells decreased with each concentration, and the cytotoxicity activity achieved was (20, 40, 45\%).
The peroxidase killed cancer cells by uptaking electrons from the lipid bilayer of cancer cells and rupturing the cancer cells in process known as lipperoxidation, and the result was agreed with (25), as shown in Fig.6.

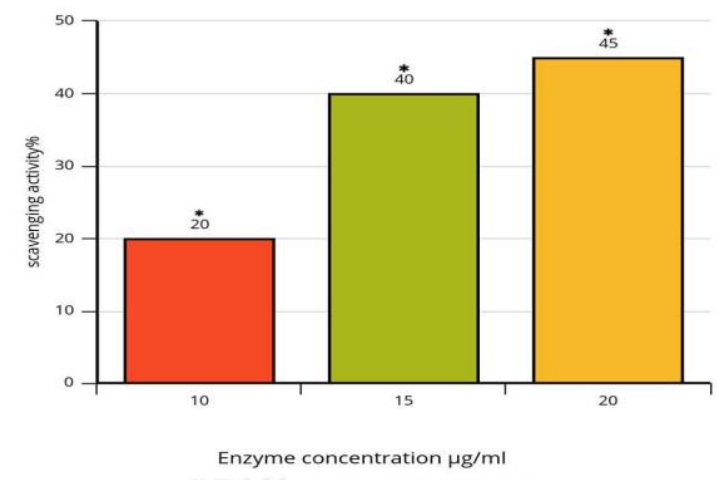

Figure 6. The effect of peroxidase enzyme produced by $P$. aeruginosa viability of cell line (MCF-7). The values represents the Mean \pm S.E $* \mathbf{P}<0.05$.

\section{Conclusion:}

The number of bacteria will be increased in the $\mathrm{pH}$ at 5.5 and decreased in the $\mathrm{pH}$ at 9, so the enzyme will be increased in the acidic $\mathrm{pH}$ and decreased in the basic $\mathrm{pH}$. The ion exchange shows the optimal purification, the high specific activity was obtained through gel filtration chromatography because the protein concentration dropping in each step. The peroxidase shows antioxidant scavenging activity because of their effect on $\mathrm{H}_{2} \mathrm{O}_{2}$ by breaking down peroxide hydrogen. This extends to anticancer activity because of the peroxidase take the electrons in the cell wall and makes disturbances in the structure and electrons of cell wall, which ruptured the cancer cells.

\section{Conflicts of Interest: None.}

\section{Reference:}

1. Kunieda K, Ohno T, Fujishima I, Hojo K, Morita T. Reliability and validity of a tool to measure the 
severity of dysphagia: the Food Intake LEVEL Scale. J. Pain Symptom Manag. Elsevier; 2013;46(2): 201206.

2. Batista KA, Batista GLA, Alves GL, Fernandes KF. Extraction, partial purification and characterization of polyphenol oxidase from Solanum lycocarpum fruits. nking). J Mol Catal B Enzym : Enzymatic. Elsevier; 2014;102: 211-217.

3. Kumar P, Sharma SM. An overview of purification methods for proteins. IJAR. 2015;1(12): 450-459.

4. Ozensoy Guler O, Capasso C, Supuran CT. A magnificent enzyme superfamily: carbonic anhydrases, their purification and characterization. J. Enzyme Inhib. Med. Chem. Taylor \& Francis; 2016;31(5): 689-694

5. Food and Drug Administration, HHS. Food Labeling: Revision of the Nutrition and Supplement Facts Labels. Final rule. FR. 2016 May 27;81(103):33741.

6. Granja A, Pinheiro M, Reis S. Epigallocatechin gallate nanodelivery systems for cancer therapy. Nutrients. Multidisciplinary Digital Publishing Institute; 2016;8(5): 307.

7. Leboffe MJ, Pierce BE. Microbiology: laboratory theory and application. Morton Publishing Company; 2012.

8. Hemraj V, Diksha S, Avneet G. A review on commonly used biochemical test for bacteria. Innovare J Life Sci. 2013;1(1): 1-7.

9. Spilker T, Coenye T, Vandamme P, LiPuma JJ. PCRbased assay for differentiation of Pseudomonas aeruginosa from other Pseudomonas species recovered from cystic fibrosis patients. Journal of clinical microbiology. Am Soc Microbiol; 2004;42(5): 2074-2079.

10. Baron EJ, Miller JM, Weinstein MP, Richter SS, Gilligan $\mathrm{PH}$, Thomson $\mathrm{Jr} \mathrm{RB}$, et al. A guide to utilization of the microbiology laboratory for diagnosis of infectious diseases: 2013 recommendations by the Infectious Diseases Society of America (IDSA) and the American Society for Microbiology (ASM) a. Clin. Infect. Dis. Oxford University Press; 2013;57(4): 22-121.

11. Liu D, Zeng X-A, Sun D-W, Han Z. Disruption and protein release by ultrasonication of yeast cells. Innov. Food Sci. Emerg. Technol. Elsevier; 2013;18: 132-137.

12. Whitaker JR, Bernhard RA. Experiments for an Introduction to Enzymology. Whiber Press; 1972.

13. Mariam SS, Ooi CW, Tan WS, Janna OA, Arbakariya A, Tey BT. Purification of rabbit polyclonal immunoglobulin $\mathrm{G}$ with ammonium sulphate precipitation and mixed-mode chromatography. Separation and Purification Technology. 2015 Apr 15;144:133-8.

14. Harrison DJ, Turner RFB, Baltes HP. Characterization of perfluorosulfonic acid polymer coated enzyme electrodes and a miniaturized integrated potentiostat for glucose analysis in whole blood. Anal. Chem. ACS Publications; 1988;60(19): 2002-2007.

15. Small H, Stevens TS, Bauman WC. Novel ion exchange chromatographic method using conductimetric detection. Anal. Chem . ACS Publications; 1975;47(11): 1801-1809.

16. Wang B, Li L, Chi C-F, Ma J-H, Luo H-Y, Xu Y. Purification and characterisation of a novel antioxidant peptide derived from blue mussel (Mytilus edulis) protein hydrolysate. Food Chem. Elsevier; 2013;138(2-3): 1713-1719.

17. Leaves L. Antioxidant Activity by DPPH Radical Scavenging Method of Ageratum conyzoides. Am J Med. 2014;1(4): 244-249.

18. Mueller H, Kassack MU, Wiese M. Comparison of the usefulness of the MTT, ATP, and calcein assays to predict the potency of cytotoxic agents in various human cancer cell lines. J Biomol Screen. SAGE Publications; 2004;9(6): 506-515.

19. Geweely NSI. Purification and characterization of intracellular urease enzyme isolated from Rhizopus oryzae. Biotechnology. 2006;5(3): 358-364.

20. Høiby N, Ciofu O, Bjarnsholt T. Pseudomonas aeruginosa biofilms in cystic fibrosis. Future microbiology. Future Medicine; 2010;5(11): 16631674.

21. Abdel-Fattah YR, Saeed HM, Gohar YM, El-Baz MA. Improved production of Pseudomonas aeruginosa uricase by optimization of process parameters through statistical experimental designs. Process Biochemistry. Elsevier; 2005;40(5): 17071714.

22. Mliki AH, Zimmermann WO. Purification and characterization of an intracellular peroxidase from Streptomyces cyaneus. Appl. Environ. Microbiol. 1992 Mar 1;58(3):916-9.

23. Zia MA, Kousar M, Ahmed I, Iqbal HMN, Abbas RZ. Comparative study of peroxidase purification from apple and orange seeds. AJB . Academic Journals (Kenya); 2011;10(33): 6300-6303.

24. Mukund S, Sivasubramanian V, Kumar NS. In vitro antioxidant activity and enzymatic and nonenzymatic antioxidant potential of Chroococcus turgidus. IJPRD. 2013;5(5): 112-120.

25. Stiborová M, Poljaková J, Ryšlavá H, Dračínský M, Eckschlager T, Frei E. Mammalian peroxidases activate anticancer drug ellipticine to intermediates forming deoxyguanosine adducts in DNA identical to those found in vivo and generated from 12hydroxyellipticine and 13-hydroxyellipticine. Int. J. Cancer. Wiley Online Library; 2007;120(2): 243251. 
استخلاص ، تنقية، توصيف انزيم البيروكسيديز من بكتريا الزوائف الزنجاريه واستخدمها كمضاد للاكسده ومضاد للسرطان

كرار رياض محمد

انتصار حسين علي

قسم العلوم التطبيقية، فرع التقنيات الاحيائيه، الجامعه التكنلوجيه، بغداد، العراق.

الخلاصة:

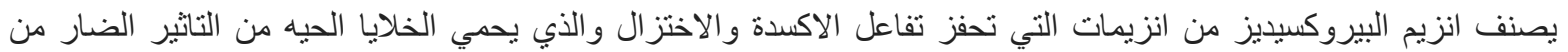

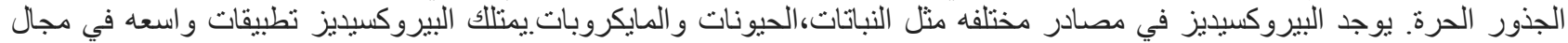

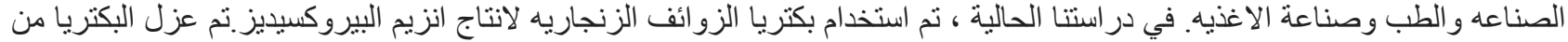

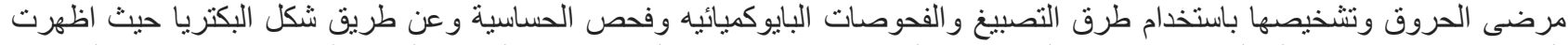

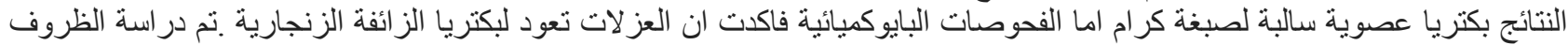

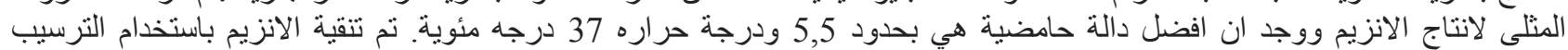

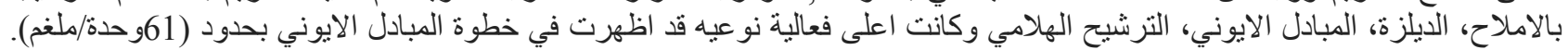

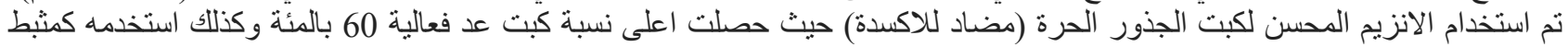
للخلايا سرطان الثذي حيث سجلت اعلى نسبة كبح للخلايا السرطانية عند تركيز (15 ملغن/مل). الكلمات المفتاحيه: مثبط للخلايا السرطان، مضاد للاكسده، خلايا سرطان الثدي، بيروكسيديز، الز ائفة الزنجاريه. 